009-8668-7

(C) Birkhäuser Verlag, Basel, 2009

\title{
Review
}

\section{The Notch signaling pathway: Transcriptional regulation at Notch target genes}

\author{
T. Borggrefe ${ }^{1, *}$ and F. Oswald ${ }^{2}$ \\ ${ }^{1}$ Department of Cellular and Molecular Immunology, Max-Planck-Institute of Immunobiology, Stübeweg 51, \\ 79108 Freiburg (Germany) Fax: ++49-761-5108-799, e-mail: borggrefe@immunbio.mpg.de \\ ${ }^{2}$ Department of Internal Medicine I, University of Ulm, Albert-Einstein-Allee 23, 89081 Ulm (Germany)
}

Received 21 October 2008; received after revision 09 December 2008; accepted 15 December 2008

Online First 21 January 2009

\begin{abstract}
The Notch gene encodes a transmembrane receptor that gave the name to the evolutionary highly conserved Notch signaling cascade. It plays a pivotal role in the regulation of many fundamental cellular processes such as proliferation, stem cell maintenance and differentiation during embryonic and adult development. After specific ligand binding, the intracellular part of the Notch receptor is cleaved off and translocates to the nucleus, where it binds to the transcription factor RBP-J. In the absence of activated Notch, RBP-J represses Notch target genes by re-
\end{abstract}

cruiting a corepressor complex. Here, we review Notch signaling with a focus on gene regulatory events at Notch target genes. This is of utmost importance to understand Notch signaling since certain RBP-J associated cofactors and particular epigenetic marks determine the specificity of Notch target gene expression in different cell types. We subsequently summarize the current knowledge about Notch target genes and the physiological significance of Notch signaling in development and cancer.

Keywords. Notch signaling, transcription, recombination signal sequence-binding protein Jkappa (RBP-JK/ CSL), chromatin and epigenetic regulation, leukemia.

\section{Introduction}

The Notch gene was discovered almost 90 years ago by Morgan and colleagues who observed that partial loss of function results in notches at the wing margin in flies (Drosophila melanogaster) [1]. Decades later in loss of function experiments, Notch was found to cause a "neurogenic" phenotype, where cells destined to become epidermis switch fate and give rise to neural tissue, reviewed in $[2,3]$. In the early eighties, the Notch gene was found to encode a $300 \mathrm{kDa}$ single-pass transmembrane receptor. The extracellular domain of

* Corresponding author.

the Notch receptor contains 36 epidermal growth factor (EGF)-like repeats essential for ligand binding. The intracellular domain is involved in cellular signaling and contains multiple conserved protein domains. Subsequently, Notch-like molecules have been identified from C. elegans (LIN-12) to humans, playing important, and apparently conserved, functional roles in development. In mammals, four Notch receptors (Notch 1-4) and five transmembrane ligands (Jagged1, Jagged2, Delta-like1, Delta-like3, and Deltalike4) are described so far. Although Notch was originally classified as a neurogenic gene even the first characterization of Drosophila embryos made it clear that Notch signals are highly pleiotropic, thereby affecting many tissues. 
The Notch signaling cascade appears remarkably simple with apparently no second messengers involved. However, the role of Notch signaling and the activation of downstream genes in a given tissue remain often complex and unpredictable. Here, we review in depth what is known so far about transcriptional regulation mediated by Notch. Subsequently, we summarize the current knowledge about Notch target genes and, in a broader context, the relevance of Notch signaling in cell differentiation and cancer.

\section{Molecular mechanism of transcriptional regulation at Notch target genes}

\section{The Notch signaling cascade}

Notch signaling is activated upon cell-to-cell contact as a result of interactions between Notch receptors and their ligands (Delta or Jagged). At the molecular level, triggering of Notch receptor by ligand binding promotes two proteolytic cleavage events at the Notch receptor (Fig. 1). The first cleavage is catalyzed by the ADAM-family of metalloproteases, whereas the second cleavage is mediated by $\gamma$-secretase, an enzyme complex that contains presenilin, nicastrin, PEN2 and APH1, reviewed in [4]. The second cleavage releases the Notch intracellular domain (NICD), which then translocates to the nucleus and acts as a transcriptional coactivator. NICD cannot bind directly to DNA but heterodimerizes with the DNA binding protein RBP-J (recombination signal sequence-binding protein $\mathrm{J} \kappa$, also called CSL, CBF1, Su(H) and LAG-1) and activates transcription of genes containing RBP-J binding sites.

Interestingly, RBP-J was originally identified as a repressor of transcription by Vales and colleagues [5]. When studying the promoter region of the adenovirus pIX gene, a 10bp repressive element was characterized and it was shown that RBP-J is the factor that binds to this element. Subsequently, the RBP-J binding site was placed in reporter assays next to other transcriptional activators Gal4-VP16 or SP1, and it was shown that RBP-J could interfere with transcriptional activation. Other investigators also demonstrated the RBP-J repressive activity by placing multiple RBP-J binding sites at a TK-promoter element [6]. The RBP-J mediated repression could either be relieved by addition of the viral activator EBNA2 (see also below section on Notch in cancer, EpsteinBarr virus) or by the fusion of RBP-J to VP16 activation domain. The RBP-J activator/repressor paradox was resolved with the realization that repression and activation via RBP-J involves the recruitment of distinct protein complexes, which influence transcription of target genes in a positive or negative fashion. In the absence of ligand, hence without nuclear NICD, RBP-J represses Notch target genes through the recruitment of corepressor complexes. NICD binding to RBP-J is crucial for the switch from repressed to activated state. NICD first displaces corepressors from RBP-J, resulting in derepression of promoters containing RBP-J binding sites and subsequently recruits a coactivator complex to activate transcription of Notch target genes.

\section{Notch target genes}

Although signals mediated through Notch receptors have diverse outcomes, only a fairly limited set of Notch target genes have been identified in various cellular and developmental contexts. The hairy/enhancer of split (Hes) genes are highly conserved proteins that are regulated by Notch in multiple cell types, reviewed in [7, 8]. Hairy/Enhancer of split family genes were first described as neurogenic genes in Drosophila (like Notch, Deltex and Mastermind), since embryos lacking the function of these genes showed an increased number of neuroblasts at the expense of epidermal precursors, reviewed in $[2,9]$. Several lines of evidence have suggested that these genes are indeed direct Notch target genes: a) The promoters of Hes1, Hes5 and Hes7 as well as Hey1, Hey2 and HeyL (subfamily of Hes, related with YRPW motif) can be activated by a constitutive active form of Notch1 [10-12], reviewed in [7]; constitutive active Notch describes a mutant of Notch that is continuously proteolytically processed and migrating to the nucleus, b) endogenous Heyl and Hey2 show an upregulation by NICD in several different cell lines [13], c) in co-culture experiments with Notch-ligand expressing cells, that achieve a more physiological level of Notch signaling, these genes are upregulated as well [13-15]; these experiments were also performed in the presence of cyclohexamide, an inhibitor of protein synthesis, to exclude secondary effects, d) $\kappa$-secretase inhibitor DAPT, which prevents cleavage of Notch, was added to Tcell leukemia cell lines which show constitutive-active Notch signaling; subsequent microarray analysis identified again members of this transcription factor family as direct Notch target genes [16]. Therefore, in mammals, the best-described Notch target genes are indeed the transcription factors Hes1, Hes5 and Hey1 $[8,17]$. Hes and Hey proteins are helix-loop-helix transcription factors that function as transcriptional repressors. Overexpression of Hes1 and Hes5 in bone marrow partly inhibits B-cell development [18]. Hes1 deficient mice are not viable and display multiple developmental defects, reviewed in [7].

CD25 (IL2-R and preTa, pre-T-cell receptor alphachain) were also shown to be Notch target genes in T- 
cells $[19,20]$. In later stages of T-cell development, the transcription factor GATA3, a master regulator for Tcell development and later for Th1/2 lineage decision, is a direct Notch target gene [21,22]. Flavell and colleagues could show that Th2-mediated immunity depends on either RBP-J or Notch [22] and that the GATA3 promoter contains bona fide RBP-J binding sites. In addition, the Pear lab demonstrated, that the expression of dominant-negative mastermindlike-1 (dnMAML) results in impaired GATA3 transcription levels and subsequently impaired IL4 production [21]. Two other Notch target genes, NRARP and Deltex-1 were shown to be potent negative regulators of Notch signaling [23, 24].

Furthermore, Notch target genes implicated in cancer are c-myc [16, 25, 26], cyclinD1 [27] and p21/Waf1 [28]. Other Notch target genes are $\mathrm{NF \kappa B} 2$ [29], Ifi202, Ifi-204, Ifi-D3, and ADAM19 [19]. A number of other genes have been reported including Notch1 itself and Notch3 [16], bcl-2 [30] and E2A [31] and HoxA5, 9 and 10 [32].

\section{What happens at Notch target genes in the absence of activated Notch?}

In the absence of Notch, RBP-J is retained at the gene regulatory elements of Notch target genes (Fig. 1) and acts there as a transcriptional repressor. Transcriptional repression seems to be mediated by different mechanisms. Based on biochemical experiments, it was proposed that RBP-J can interact directly with TFIID, a general transcription factor [33] or that RBP$\mathrm{J}$ can recruit histone deacetylase-containing complexes. Previously, at least three different interactions between RBP-J and corepressor complexes have been described: a complex containing SMRT/mSin3A/ HDAC-1 (SMRT, Silencing Mediator for Retinoic acid and Thyroid hormone receptor; HDAC-1, histone deacetylase-1) or NCor/mSin3A/HDAC-1 complex [34] and a CIR/SAP30/HDAC-2 complex [35]. So far, the functional relevance of these biochemical findings still remains to be seen.

We recently characterized an RBP-associated repressor complex composed of corepressors RBP-J, SHARP (SMRT and HDAC associated repressor protein), CtBP (C-terminal binding protein) and CtIP (CtBP interacting protein) [36]. The relevance of this finding is supported by genetic data in Drosophila where RBP-J homologue $\mathrm{Su}(\mathrm{H})$ can recruit the corepressor dCtBP [37, 38]. Analogous to Drosophila dCtBP mutants, CtBP knock-out mice reveal that this protein plays a pivotal role in embryogenesis [39]. By now, several other groups have shown that $\mathrm{CtBP}$ is found in complex with histone demethylase LSD1/CoREST [40] (see also below).

\section{Epigenetic regulation of Notch target genes}

Although precise mechanisms of epigenetic regulation at Notch target genes are not completely understood, cumulating evidence suggests that histone modifications play a pivotal role in this process. The presence of specific post-translational histone modifications define transcriptionally inactive or active chromatin domains [41-44]. Acetylation and methylation represent the most common modifications of the histone tails. This epigenetic, or non-DNA encoded information, at promoters determines the outcome of a transcriptional response in a specific cell type. The precise mechanisms of epigenetic regulation of Notch target genes are not yet known, although some histone-modifying enzymes have been implicated in the regulation of Notch target genes. The histone acetyltransferase (HAT) p300 has been shown in complex with RBP-J/Notch and is a positive cofactor for Notch dependent transcription [45, 46]. Functional interactions between Notch and PCAF and GCN5 have also been observed [47]. Furthermore, histone deacetylases have been implicated in repression mediated by the RBP-J/SHARP corepressor complex $[34,48]$.

There is only very preliminary data available for changes in histone methylation at Notch target genes. So far, Bray and colleagues could demonstrate that dynamic changes in histone methylation of $\mathrm{H} 3 \mathrm{~K} 4$ occur upon activation of Notch target genes [49]. Interestingly, in Drosophila Bre1, the histone H2B ubiquitin ligase, regulates not only activation of some Notch target genes but also H3K4 methylation [50]. On the other hand, the mammalian histone H3K4 demethylase LSD-1 has been implicated in Notch target gene regulation [51]. The involvement of LSD-1 in the regulation of Notch signaling is further supported by genetic data in C. elegans [52]. Baumeister and colleagues used a suppressor screen of presenilin (C. elegans sel-12), displaying an egg-laying defect and identified members of the HDAC/CoREST/LSD1 complex as genetic interactors. Interestingly, LSD-1 is also part of a corepressor complex containing CtBP [40] which is one component identified in the RBP-J corepressor complex [36-38,53]. Specific polycomb complexes, that are known to methylate H3K27, have been proposed to play a negative role in the regulation of Notch target genes [54, 55]. In addition, polycomb component YY1, which is itself a DNA binding protein, has been found to be associated with NICD, to regulate c-myc promoter activity [56]. Interestingly, overexpression of the two polycomb epigenetic silencers, Pipsqueak and Lola, enhance Notch-induced overproliferation and causes hypermethylation at the $\mathrm{Rb}$ tumor suppressor gene [57]. 
Finally Bray and colleagues also reported that the histone $\mathrm{H} 3 / \mathrm{H} 4$ chaperone Asf1 contributes to repression of Notch target genes, as depletion of Asf1 by RNAi caused derepression of some Notch target genes and Asf and Notch interact genetically [58].

\section{The RBP-J corepressor and coactivator complexes}

\section{RBP-J corepressor complex}

RBP-J is the only transcription factor in the Notch signaling cascade and is therefore a central player. In the absence of Notch, RBP-J recruits a corepressor complex that contains different components at different Notch target genes. In the presence of NICD, the corepressor complex is displaced and a coactivator complex containing Notch and Mastermind is recruited (Fig. 1).

RBP-J itself. RBP-J $\kappa$ [59] also called CBF1 or KBF2 [60] belongs to the CSL-protein family. CSL stands for CBF1 (human), [61], Suppressor of Hairless (Drosophila), [62], Lag-1 (C. elegans), [63]. RBP-J (mouse) [64], was first isolated from B-cells as a $60 \mathrm{kDa}$ DNAbinding protein [59]. It is a highly conserved nuclear protein with $75 \%$ sequence amino acid sequence identity between human and Drosophila [62] that is ubiquitously expressed. The DNA binding sequence was identified as 5'-CGTGGGAA-3' [64]. A paralogue of RBP-J, RBP-L, was also described that is almost exclusively expressed in the lung [65]. RBP-L binds to DNA identical to RBP-J. Although RBP-L did not interact with any Notch protein, it was shown to cooperate with EBNA2 in transcriptional activation. RBP-L has been also found in complex with PTF1, which has been proposed to play a role in pancreas development [66]. The physiological role and possible redundancy of the two RBP factors is still unknown.

The essential function of RBP-J has been demonstrated by knock-out models in mice where the loss of RBP-J expression exhibited an lethal phenotype in embryonic development at day 10.5 of gestation. Conditional deletion in the hematopoietic system leads to a block in T-cell development and ectopic development of B-cells in the thymus [68]. This phenotype is very similar to Notch1 conditional knock-out mice, indicating that "canonical" Notch signaling (signaling through RBP-J) is the main pathway in lymphoid development.

SKIP (Ski-interacting protein), originally identified by the Hayward lab in a yeast-2-hybrid screen with RBP-J, is evolutionary highly conserved [69]. When part of the corepressor complex, SKIP can interact with corepressor SMRT, thereby recruiting histone deacetylases [34]. Hayward and colleagues have presented data that demonstrates SKIP bridges interactions between RBP-J and corepressors or RBP-J and Notch $[69,70]$. This implies that SKIP is part of both RBP transcriptional repression and activation complexes. However chromatin immunoprecipitation experiments from the Jones group suggest that SKIP is only recruited to the promoter when Notch is present [71].

CIR (CBF1 interacting corepressor) is, like SKIP, also a direct RBP-J binding protein that binds also to HDACs and SAP30 [35]. The function and in vivo relevance of SKIP and CIR still remains to be addressed. The role of histone deacetylases in the RBP-J corepressor complex has been reported by several groups $[34,35,48,72]$. HDAC1/2 are also part of the LSD1/CoREST/CtBP complex [40].

KyoT2 is a LIM domain protein and interacts with RBP-J through the binding motif on its C-terminus generated by alternative splicing [73]. It has been shown that KyoT2 can block Notch- or EBNA2 mediated transactivation. KyoT2 has also been shown to recruit Polycomb group proteins HPC2 and Ring1 [54,74].

SHARP (SMRT and HDAC associated repressor protein) was originally found in a yeast-2-hybrid screen with SMRT (Silencing Mediator for Retinoid and Thyroid hormone receptor) as a cofactor for nuclear hormone receptors [75]. In our own experiments, the corepressor protein SHARP was found to interact directly with transcription factor RBP-J [48]. SHARP is a $400 \mathrm{kDa}$ nuclear protein that is ubiquitously expressed. It is a member of the heterogeneous SPEN-homology (Split-ends) domain family implicated in biological processes from embryogenesis to ageing. SHARP contains RRMs (RNA Recognition Motifs) in the amino-terminal region and a highly conserved SPOC-domain at the very C-terminus [76] and reviewed in [77]; this domain has been crystallized and contains a highly conserved positively charged patch which is crucial for the interaction with corepressors SMRT/NCoR[78,79]. The very last 34 amino acids of the SPOC-domain of SHARP are required for binding to corepressors CtIP/CtBP [36] and ETO (Eight-twenty-one) (Fig. 1) [78, 79]. In addition, the SPOC-domain of SHARP can be phosphorylated by Pak1 (p21-activated kinase-1), and hence enhances SHARP corepressor function. It also has been reported by the group of Han that the SHARP C-terminal SPOC-domain can homodimerize [80]. 
The mouse homolog of SHARP, MINT (Msx-2Interacting Nuclear Target), was found in a screen for interacting proteins of transcriptional repressor Msx-2 (Muscle segment homeobox-2), [81]. MINTdeficient mice are embryonic lethal, due to defective heart, pancreas and hematopoietic development [82]. In fetal-liver transfer experiments, the Honjo group could show that MINT-deficient splenic B cells differentiated about three times more efficiently into marginal zone $\mathrm{B}$ cells with a concomitant reduction of follicular B cells. This is in agreement with the finding that Notch directs differentiation into marginal zone B-cells. Conditional MINT knock-out mice recapitulate the results from fetal liver transfer experiments [83] and reveals negative regulation of early thymocyte differentiation by Notch/RBP-J signaling [84].

Our functional and biochemical findings as well as the genetic data from Honjo and colleagues suggest that SHARP might be the functional homolog of Drosophila Hairless. In Drosophila melanogaster the $\mathrm{Su}(\mathrm{H})$ interacting protein Hairless $(\mathrm{H})$ is the major platform for $\mathrm{Su}(\mathrm{H})$ dependent corepressor complex assembly. It is important to note here, that so far Hairless proteins cannot be identified within higher eukaryotes. For more detailed information, readers are referred to a recent review [85].

Interestingly, there is a SHARP-like protein in mouse and men, Rbm15/OTT1, that is implicated in acute megakaryoblastic leukemia [86, 87] and has been shown to interact with RBP-J, although the RBP-J binding site of SHARP is not conserved in Rbm15/ OTT1 [88]. Rbm15/OTT1 deficient mice are characterized by a loss of peripheral B-cells and an increase in stem- myeloid- and megakaryocyte progenitors [89].

Furthermore, the proteins SHARP, OTT1 and SKIP were identified as spliceosomal components [90] and therefore may also be implicated in post-transcriptional processes [91].

\section{SHARP as a "corepressor hub": CtIP/CtBP, ETO and $S M R T$}

Several lines of evidence suggest that SHARP can be involved in recruitment of different corepressor complexes which demonstrates the versatility of Notch regulated gene expression. It is intriguing that, CtIP, ETO and SMRT bind to the same small region of the large $400 \mathrm{kDa}$ protein SHARP.

In the absence of NICD, the RBP-J/SHARP heterodimer recruits corepressors CtIP/CtBP to Notch target genes [36], (Fig. 1A). As mentioned above, this is particularly interesting because of the biochemical and genetic interaction to histone demethylase LSD-1, which was identified as a component of the
CtBP corepressor complex [40]. Furthermore, Drosophila Hairless, the functional homolog of SHARP, recruits corepressor $\mathrm{dCtBP}$ as well.

Moreover, we most recently demonstrated that ETO is an additional component of the SHARP corepressor complex [78], (Fig. 1B). Interestingly, leukemogenic fusion protein AML1/ETO can disturb the normal, repressive function of ETO at Notch target genes. This activating (or derepressing) effect of AML1/ETO may contribute to its oncogenic potential in myeloid leukemia. Our data is supported by the group of Pelicci who performed overexpression of leukemogenic fusion protein AML1/ETO and observed deregulation of some Notch target genes [92]. It still remains to be characterized in detail, which corepressor is utilized at certain target genes in specific cell types. Only in a few cases, like that of SHARP, this was answered in part.

\section{Coactivators of Notch}

After engagement of the Notch receptor, proteolytic cleavage events release the intracellular domain of Notch (NICD), which then translocates into the nucleus to displace RBP-J associated corepressors and then recruits coactivators.

NICD itself. The best-described intracellular domain of Notch1 contains five different segments: i) seven tandem-ankyrin repeats, ii) the transactivation domain, iii) a glutamine-rich OPA domain, iv) a proline-, glutamine-, serine- and threonine-rich PEST domain and v) a RAM23 domain [93-95]. The RAM23 domain contains the nuclear localization signals (NLSs) and is in combination with the ankyrin-repeats responsible for the binding to RBP-J [94,96]. The region between the ankyrin-repeats and the PEST region is the transactivation domain (TAD) of NICD, [97]. Recently, three other functional regions of NICD have been identified, termed PPD (potential phosphorylated domain), DTS (downregulation targeting sequence) and S4 (for WSSSSP). PPD is located between the ankyrin repeats and PEST domain and was shown to enhance the binding of NICD to RBP-J [98]. DTS is required for endocytic trafficking of Notch and crosstalk with the Ras signaling pathway [99]. S4 is the C-terminal phosphorylation site, important for Notch turnover (see below: $\mathrm{CycCl}$ Cdk8 and phosphorylation of Notch receptor and Fig. 1). NICD is the central player in the nucleus. Unfortunately, many different laboratories use different NICD constructs, either with the C-terminal OPA/ PEST or without, most of them from mice, but some also human, making the interpretation of results of different groups difficult to compare. The Notch modifications (glycosylation, phosphorylation, ubiq- 


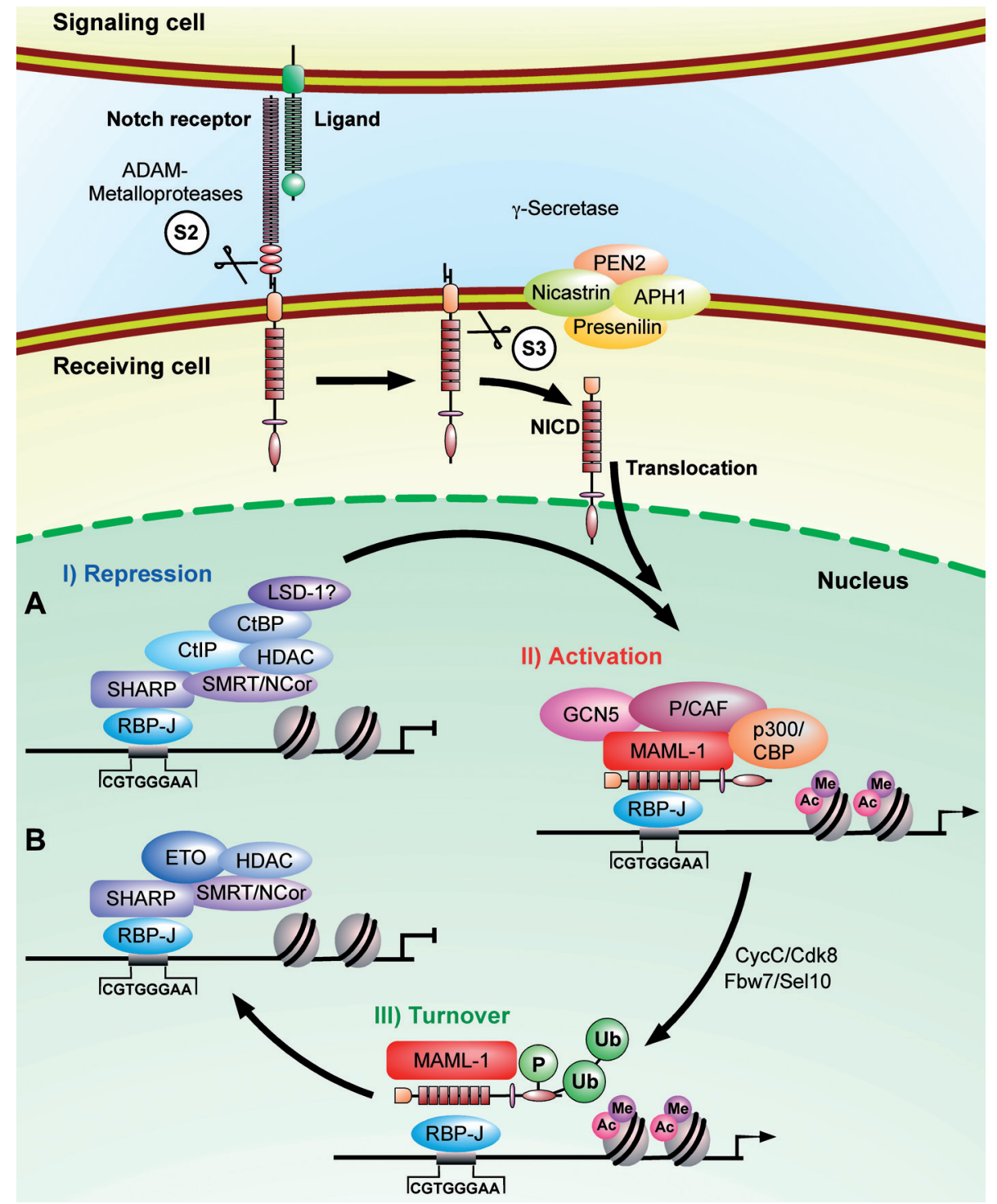

Figure 1. Molecular steps involved in Notch signaling. Notch ligands and Notch receptors represent proteins with a single transmembrane spanning domain. During protein maturation, the precursor of the Notch receptor is cleaved by a furin-like convertase in the trans Golgi network and the resulting fragments are transported to the cell surface as a non-covalently linked heterodimeric receptor molecule (not shown). I. Repression of Notch target genes. In the absence of activated Notch signaling, the DNA-binding protein RBP-J recruits corepressor complexes to represses transcription of Notch target genes. Two pivotal corepressor complexes are shown where RBP-J interacts with the central corepressor protein SHARP $(A$ and $B)$. In these complexes SHARP serves as a protein interaction platform recruiting $\mathrm{CtIP} / \mathrm{CtBP}(A)$ or ETO $(B)$ together with additional corepressors and histone modifying enzymes. II. Activation of Notch target genes. Upon Notch ligand binding an ADAM-type metalloprotease catalyzes a specific cleavage step (S2) at the Notch receptor. Subsequently, a further cleavage step (S3) catalyzed by a $\gamma$-secretase containing complex, releases the intracellular domain of Notch (NICD) that migrates to the nucleus. NICD interacts with RBP-J and recruits a coactivator complex composed of Mastermind (MAML-1) and other chromatin modifying transcription factors resulting in the transcriptional activation of Notch target genes.

III. NICD degradation and turnover of the coactivator complex. NICD phosphorylation facilitated by the mediator components CyclinC/ Cdk8 and ubiquitinylation via the E3 ubiquitin ligase Fbw7/Sel10 results in rapid NICD degradation and turnover of the coactivator complex. Subsequently, newly established RBP-J associated corepressor complexes shut-down transcription of Notch target genes. Further information is given in the text.

uitinylation), proteolytic cleavage events as well as mutations associated with leukemia development have been extensively reviewed elsewhere and are beyond the scope of this review $[4,100]$.
Mastermind/p300. Mastermind is a member of the Mastermind-like (MAML) family of coactivators [101, 102], originally identified in genetic screens in Drosophila [2]. Recently, the first detailed view of the coactivator complex was provided by the determination of the structure of full-length RBP-J bound to 
DNA in combination with a truncated form of NICD and the interacting part of MAML [103] and reviewed in $[104,105]$. In Drosophila, the mastermind gene codes for a glutamine-rich protein, indicative for an transcriptional activators. Mammalian MAML was shown to stabilize the RBP/NICD bound to DNA during activation of target genes [102]. In vivo, the importance of MAML has been impressively demonstrated with dominant-negative MAML, which completely blocks all Notch-mediated transcriptional activation [106]. This tool has been exploited to study the physiological role of "canonical" (RBP-J dependent) Notch signaling in detail, reviewed in [107].

The ternary complex of RBP-J/NICD/MAML recruits histone acetyltransferase p300 to activate Notch target genes [45, 46, 108]. The Capobianco lab set out to purify the endogenous Notch-coactivator complex [109]. Using nuclear extracts from a T-cell leukemia line (SupT1), they could demonstrate in gel filtration experiments that this complex peaks at $1-1.5 \mathrm{MDa}$ in size. The identity of further components still remains unresolved.

\section{Structure of the RBP-J/NICD/MAML coactivator complex}

The first detailed view of the transcription factor RBP-J (CSL) was provided by the determination of the structure of the C. elegans ortholog, Lag-1, bound to cognate DNA [110]. The structure revealed that RBP-J is composed of three domains: N-terminal (NTD), beta-trefoil (BTD) and C-terminal (CTD). The $\mathrm{N}$ - and C-terminal domains share structural similarities with the Rel-homology domain similar to those of NF-KB and NFAT proteins, reviewed in [104]. Previous biochemical and cellular studies demonstrated that both NICD and corepressors interact primarily with CSL through a central region corresponding to the beta-trefoil domain, reviewed in [104]. NICD primarily interacts strongly through its RAM-domain, but only weakly through its ankyrin repeats [94]. However, the ankyrin repeats are needed for the formation of the RBP-J/NICD/MAML ternary complex and transcriptional activation [10].

Several structures have been determined for the ankyrin repeats of NICD, including orthologs of mammals, D. melanogaster and C. elegans, reviewed in [104]. The ankyrin repeat fold is a common proteinprotein interaction motif and is composed of multiple repeats that form an elongated molecule; Each repeat contains two alpha helices connected by a turn and a beta-hairpin motif. Recently two ternary complex structures of RBP-J/NICD/MAML bound to DNA were determined for C.elegans [111] and human orthologous proteins [103]. The ternary complex reveals that Mastermind adopts a strikingly bent helical conformation, forming a tripartite structure with ankyrin repeats 3-7 of NICD and the C-terminal domain of RBP-J (Fig. 2). The crystal structures illuminate some of the molecular details fundamental to RBP-J and NICD. One should keep in mind that apart from RBP-J, only relatively small fragments of NICD and MAML were resolved. Understanding the complete coactivator complex, both functionally and structurally, remains a tremendous task for the future.

\section{Negative regulators of activated Notch signaling}

NRARP and Deltex proteins are both important negative feedback regulators of Notch receptor mediated signaling. NRARP was first discovered in Xenopus and is a small 114 a.a. ankyrin-repeat containing protein [24]. NRARP is not only a direct Notch target gene [112] but interacts physically with NICD and blocks Notch-mediated transactivation and $\mathrm{T}$ lineage commitment [113, 114]. A similar observation was described for Deltex-1 [115]. Enforced expression of Deltex-1 in hematopoietic progenitor cells results in B-cell development at the expense of T-cell development [23]. However, in loss of function experiments, T-cells that lack Deltex-1 and Deltex-2 develop normally [116]. This means that endogenous levels of Deltex-1 and Deltex-2 are not important for regulating Notch signals.

CyclinC/Cdk8 and phosphorylation of Notch receptor The Jones group has shown that Mastermind recruits CyclinC/Cdk8, which is part of the repressive Mediator complex [71]. This Cyclin/Cdk pair strongly enhances NICD phosphorylation and PEST-dependent degradation after ubiquitinylation by the Fbw7/ Sel10 ubiquitin ligase (Fig. 1). The authors conclude that CyclinC/Cdk8 is important for Notch activation and turnover. The importance of Cdk8 as Notch kinase is challenged by the group of J. Aster; in this study a dominant-negative Cdk8 fails to affect the difference in NICD wild type and NICD mutated at all putative Cdk8 phosphorylation sites [117]. Thus, the role of $\mathrm{CyclinC} / \mathrm{Cdk} 8$, and therefore of Mediator, remains controversial so far.

\section{Notch signaling in development and differentiation}

Notch signaling is activated upon cell-to-cell contact as a result of interactions between Notch receptors and their ligands Delta or Jagged. Signaling mediated by Notch receptors and ligands is involved in regulation of many biological functions, such as apoptosis, cell proliferation, differentiation and lineage decisions during embryonic development, and homeo- 


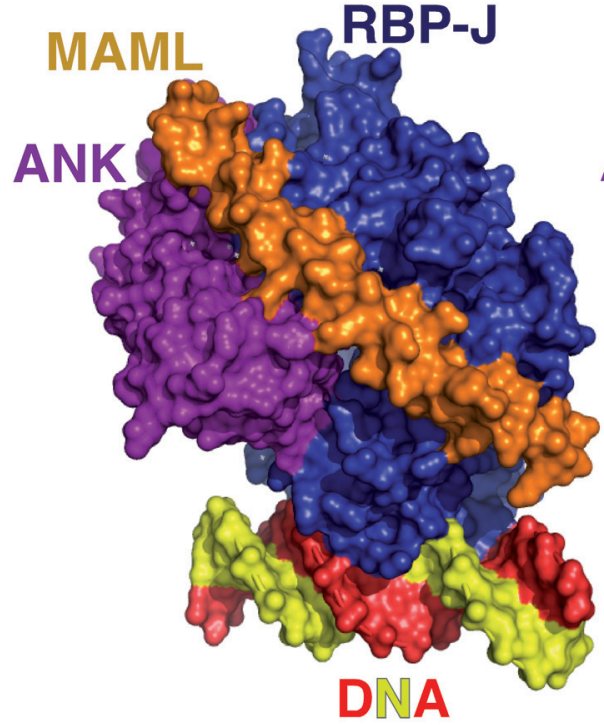

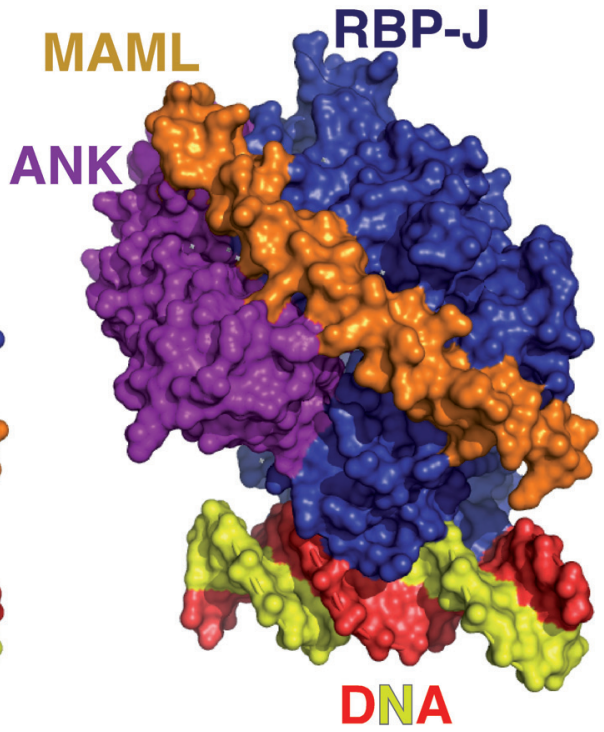

Figure 2. Stereo-view of the DNA/RBP-J/Notch/MAML coactivator complex. RBP-J (also called CSL) colored in blue binds to a DNA oligonucleotide (red and yellow). The ankyrin repeats (ANK) of Notch intracellular domain (NICD) are displayed in purple. A polypeptide of Mastermind (MAML), displayed in orange, is sandwiched between the RBP-J and NICD. Stereo-view was established with the $2 \mathrm{~F} 8 \mathrm{X}$ dataset (103) using the PyMOL software. stasis of adult self-renewing organs, reviewed in $[2,4]$. In Figure 3, we summarize the different mechanisms of how Notch influences these key developmental decisions. Lateral inhibition (Fig. 3A) occurs during neurogenesis where a group of equipotent cells expressing equal amounts of Notch receptor and ligand begin to gradually express either Notch receptor or Notch ligand. In the case of lateral induction (Fig. 3B), the Notch ligand is provided by a different cell in close proximity. A well-studied example for this is lymphopoiesis where a common lymphoid progenitor develops into a pre-T cell, in case a thymic stromal cell provides the inductive signal. In the absence of the inductive signal, i.e., in the bone-marrow environment, the common lymphoid progenitor differentiates into a B-cell with the help of bone marrow stromal cells. Notch can also maintain stem cell state and act as a gatekeeper (Fig. 3C). An example for this is the intestine where Notch prevents the crypt progenitor cells (TA) from differentiating. On the other hand, Notch signaling can also drive a terminal differentiation program (Fig. 3D) by inducing cell cycle arrest like it is observed in keratinocytes in the skin.

\section{Notch regulates binary cell fate decisions and stem cell maintenance}

Notch signaling has been extensively studied first in Drosophila. The classical example is that Notch signaling restricts cell fates in the neural-epidermal choice. Special groups of cells known as proneural clusters have neuronal potential because of their expression of proneural helix-loop-helix transcriptional regulators. Notch signaling restricts neural differentiation by repressing the expression of proneural genes [118]. Failure to activate Notch signaling leads to formation of more neuronal clusters because of enhanced expression of proneural genes; constitutive activation of Notch signaling leads to the contrary and suppresses neural differentiation, reviewed in [2, 4] (Fig. 3A). Many proteins that mediate neuronal repression in Drosophila are encoded by the Enhancer of Split complex, reviewed in [7, 119]. Therefore, Notch signaling seems to be an evolutionary conserved pathway for preventing equipotent cells from acquiring the same fate.

In vertebrates, Notch signaling also represses neurogenesis (and myogenesis) via helix-loop-helix repressors called Hairy/Enhancer of split, or Hes, transcriptional repressors mentioned above. Taylor and colleagues could demonstrate that conditional ablation of Notch1 in mice leads to premature onset of neurogenesis [120]. Subsequently, they could show that Notch1 signaling is required for both neuron and glia formation. Using transgenic Hes5 promoter coupled to a GFP-reporter, two groups could show that the GFP expressing cells have self-renewal capability and multipotency in transplantation assays [121, 122].

An example of Notch signaling in vertebrates involved in stem cell maintenance is the intestinal crypt compartment in the gut, a highly proliferative tissue, reviewed in [123]. Post-natal gut specific inactivation of RBP-J results in the complete loss of proliferating transient amplifying (TA) cells [124]. In a reciprocal experiment, expression of activated Notch1 (NICD) in the gut inhibits differentiation of crypt progenitors [125]. These genetic experiments establish Notch signaling as a gatekeeper for intestinal crypt cells in mice. In pharmacological experiments using $\gamma$-secre- 
tase inhibitor (GSI), which inhibits cleavage of Notch, transient amplifying cells are lost [126].

\section{Notch induces terminal differentiation}

A second general role of Notch is to promote the development of a given cell type or body region, often by inducing the expression of positively acting regulatory molecules. For example, in Drosophila wing development, Notch signaling specifies the wing margin, a line of cells that organizes the outgrowth of the wing by activation of the gene vestigal, reviewed in [119]. In mammals, Notch signaling initiates a terminal differentiation program in human skin [127, 128]. In mouse keratinocytes, Notch signaling stimulates expression of early differentiation markers and enhances the expression of cell cycle regulator p21/ Waf1, causing cell-cycle arrest of basal cells and thus allowing onset of differentiation [28] (Fig. 3D).

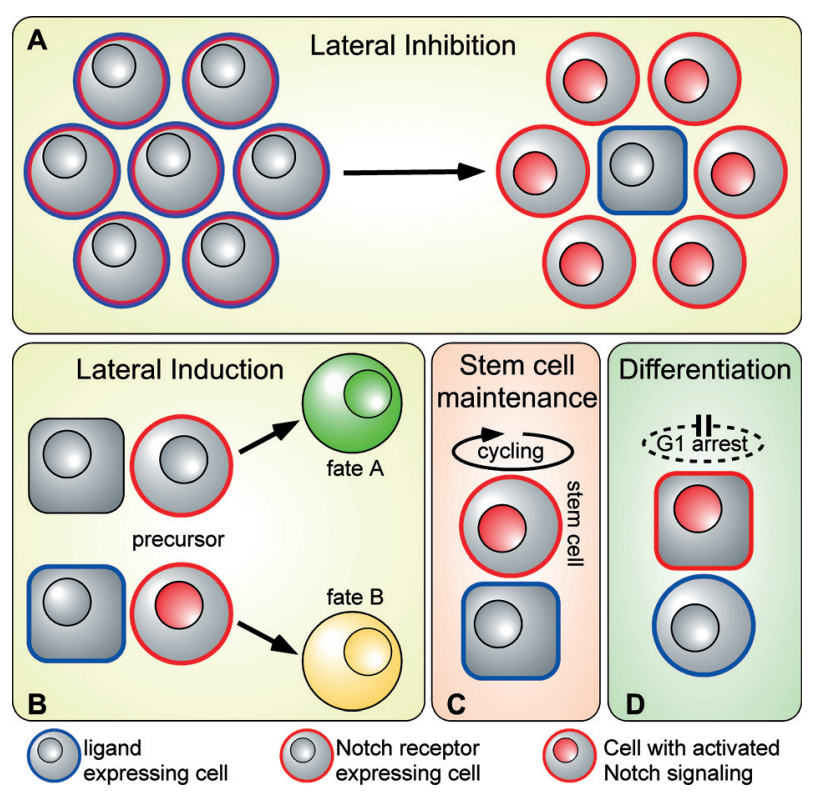

Figure 3. Notch functions in development and differentiation. Notch signaling has different effects in different organs and tissues. A and B: Notch in binary cell-fate decisions. A: Within a group of cells of the same type which express equal amounts of ligands and Notch receptors (left) a single cell starts to differentiate e.g., into a neuronal precursor cell with increased surface expression of ligand (right). The ligand activates the Notch signaling cascade in the neighboring cells, thereby inhibiting differentiation into neuronal precursor cells. B: A precursor cell (e.g., early lymphoid precursor cell) is instructed to adopt fate A (e.g., B cell) in the absence of a Notch ligand (upper) from a different cell type (e.g., stromal cell). In the presence of Notch ligand, the Notch pathway is activated (lower) to instruct the precursor cell to adopt fate B (e.g., T cell). C: A particular cell type induces Notch signaling in stem cells to maintain an undifferentiated state (e.g., stem cells within the intestinal crypts). D: Ligand expression in a precursor cell can activate the Notch pathway to initiate terminal differentiation and cell cycle arrest in descendant cells (e.g., keratinocytes in the skin).

\section{Notch in hematopoiesis}

Fetal/adult stem cells

In development, Notch is essential for the emergence of definitive hematopoietic stem cells during fetal life [129]. During the onset of definitive hematopoiesis in the embryo, Notch1/RBP-J dependent signaling leads to the activation of GATA-2 [130], which has been shown to be an essential transcription factor for hematopoiesis [131]. Whether Notch signaling is similarly important for adult hematopoiesis remains controversial: Several studies using overexpression of activated form of Notch1 in primary cells as well as stimulation of hematopoietic stem cells with Notch ligand suggest that Notch inhibits differentiation leading to increased self-renewal, reviewed in [132]. In addition, Reya and colleagues used a transgenic Notch reporter mouse, with RBP-J responsive elements driving a GFP reporter, and could show that Notch signaling is active in GFP + adult hematopoietic stem cells (HSCs) and is reduced in differentiated cells [133]. Inhibition of Notch leads to accelerated differentiation of HSCs in vitro and depletion of HSCs in vivo. On the other hand, none of the loss-of-function studies have demonstrated a role for the Notch/RBP-J signaling pathway in hematopoietic stem cell maintenance. Neither inducible knock-out of RBP-J [68], Notch1 [134] or Jagged1 [135] have led to a reduction of hematopoietic stem cells. In addition, Pear and colleagues showed that HSCs that carry dominantnegative mastermind (dnMAML) can engraft normally in bone-marrow transplantation assays, and that normal frequencies in long-term reconstitution assays are achieved in both the presence or absence of dnMAML [136].

\section{T-cell development}

The best-studied example in mammals is how Notch signaling determines a hematopoietic progenitor cell to differentiate into a T-lymphocyte (Fig. 3B). The importance of Notch signaling for the induction of $\mathrm{T}$ cell fate was first demonstrated in mice in which the Notch1 gene was conditionally deleted using Mx-Cre. These mice exhibited a complete block in T-cell development at an early stage of differentiation and an emergence of ectopic B-cell development in the thymus [134]. Conversely, overexpression of constitutive-active Notch (NICD) in the bone marrow instructed a T-cell fate in bone marrow progenitors and inhibited B-cell development [137]. The same effect was observed after overexpression of Delta4 in the thymus [138]. Ex vivo, this phenomenon has been exploited using bone marrow stromal cell lines expressing Notch ligand Delta-like1. T-cell precursors can be efficiently generated by co-culturing hemato- 
poietic progenitors on these stromal Notch-ligand expressing cells [139].

Notch signaling also potentially plays a role in the development of gamma/delta T-cells and natural killer cell development, reviewed in $[107,140]$. Recent data also indicate that Notch signaling can direct the differentiation and activity of peripheral T-cells, reviewed in [107, 141]. During helper T-cell differentiation, Notch is involved in generating optimal Th2 cell responses by upregulating GATA 3 and thereby promoting IL-4 expression $[21,22]$.

\section{Notch and B-cell development}

In addition to its well-established function in T-cell development, Notch signaling is important for later stages in B-cell development. Early stages of B-cell development do not depend on Notch signaling components and the B-cell master regulator Pax-5 even suppresses Notch1 expression, reviewed in [142]. Although Notch1 is the key Notch receptor during Tcell development, Notch-2 is the crucial receptor to fulfill functions in B-cells. Notch-2 is essential for the development of splenic marginal zone B-cell whereas it is dispensable for follicular B-cell [143]. This decision depends on Notch-2, its ligand Delta-1 as well as on RBP-J, reviewed in [140]. Recently, it was also shown that Notch signaling plays an important role in the terminal differentiation of mature B-cells into antibody-secreting cells [144] and that Notch activity can synergize with the B-cell receptor and CD40 signaling to enhance B-cell activation [145].

\section{Notch in myeloid/erythroid differentiation}

It has been shown that Notch1/RBP-J positively regulates apoptosis during erythroid development [146]. However, its role in myelopoiesis remains unclear and controversial. On the one hand, some in vitro studies show that activated Notch signaling inhibits differentiation of myeloid precursors [147149]. This is also supported by a recent work using a conditionally induced null mutation in the FX locus, that results in a myeloproliferative phenotype [150]. FX encodes an essential enzyme in the GDP-fucose synthesis pathway. In addition, FX is essential for the fucosylation of the EGF repeats of Notch, a crucial post-translational modification for proper Notch function [4]. On the other hand the group of Just has shown that a conditionally NICD, fused to the ligand binding domain of estrogen receptor promotes myeloid differentiation [151]. In loss-of-function studies, Radtke and colleagues could show that in conditional Notch1 deficient mice development of granulocytes, macrophages and dendritic cells is normal [152]. The same holds true for conditional RBP-J deficient mice [68]. In addition, in mice reconstituted with stem cells carrying a dominant negative form of Mastermind (dnMAML, see above), development of myeloid compartment is also not affected [136].

For further detailed information, readers are referred to several excellent in-depth reviews on the topic of Notch signaling in hematopoiesis, especially lymphopoiesis $[107,140,153,154]$.

\section{Notch signaling in cancer}

There is increasing evidence that Notch signals are oncogenic in many cellular contexts, for example in Tcell leukemia (T-ALL), breast and colon cancer, reviewed in [123, 155]. Notch-4 was first identified as a proviral integration sites, named int-3, in retrovirus-induced murine mammary cancer [156]. Whether Notch4 plays a genuine role in normal mammary development remains unclear so far.

\section{Notch and leukemia}

The definite example of oncogenic Notch signaling is found in T-acute lymphoblastic leukemia (T-ALL), an aggressive neoplasm of immature T-cells. Human Notch was originally identified at a chromosomal breakpoint of a subset of T-ALLs containing a $t(7 ; 9)$ chromosomal translocation. These leukemic cells express a truncated Notch1 allele (TAN1), that encodes a constitutive-active Notch1 polypeptide [157] reviewed in [100] and [123]. In support of this, many studies in mice have subsequently revealed that expression of constitutive-active Notch proteins leads to potent and specific induction of T-ALL [158]. Aster and colleagues searched for specific Notch1 mutations in T-ALLs that do not harbor the $\mathrm{t}(7 ; 9)$ translocation and identified two hotspot regions in the Notch1 gene: the heterodimerization and the PEST-domain [159]. Mutations in the heterodimerization domain enhance S3 cleavage of Notch and cause, via augmented NICD production, a significant increase in Notch signaling. Genetic and biochemical data suggest that loss of the PEST-domain enhance NICD protein stability, reviewed in [160]. Synergistic heterodimerization and PEST domain mutants are found together in cis in 10 $20 \%$ of human T-ALLs [159] and low copy number amplification of Notch1 has also been reported [161]. Notch mutations appear to collaborate with a diverse collection of other proteins dysregulated in T-ALL. Retroviral oncogenesis in mice indicates a synergistic interaction between Notch1 and c-myc [162], E2A/ pbx [163] and dominant negative forms of Ikaros [164] to enhance development of T-ALL.

Apart from Notch1, Notch3 was consistently expressed in human T-ALL and dramatically reduced in clinical remission [165]. It was shown by the 
Screpanti group that Notch target genes Hes1 and preT $\alpha$ are associated with Notch3 expression. Expression of these genes is restricted to thymocytes and usually not seen in normal mature peripheral T-cells. Thus, the expression of Hes1, Notch3 and preTa characterizes the active and relapsing face of T-ALL, reviewed in [123].

\section{Notch target genes and herpes viruses (Epstein-Barr and Kaposi's sarcoma-associated herpes viruses)}

The Epstein-Barr virus nuclear antigen 2 (EBNA2) and NICD have been shown to be partially interchangeable, reviewed in [166]. Therefore EBNA2 has been proposed to be the functional homolog of NICD. EBNA2 is a transcriptional transactivator that is one of the first viral genes expressed after EBV infection of B-cells and is essential for Epstein-Barr virus (EBV) immortalization of B-cells in vitro $[167,168]$. EBNA2, like NICD, does not bind to DNA directly, but needs the transcription factor RBP-J [169, 170]. Recombinant viruses carrying an EBNA2 gene that lacks the RBP-J interaction domain are no longer able to immortalize B-cells [171]. EBNA2 and NICD are found to regulate the same cellular and viral promoters and both have been shown to be partially interchangeable in regard to activation of target genes in B-cell lines and modulation of differentiation processes, reviewed in [166].

In addition to EBV, the lytic switch protein RTA of Kaposi's sarcoma-associated herpes virus (KSHV) has been found to bind to RBP-J [172], reviewed in [173]. KSHV establishes latency in B-cells, like EBV, but can also infect endothelial cells. Other viruses that have interactions with the Notch pathway are adenovirus, HPV and simian virus 40 (SV40), reviewed [173]. The first association of adenovirus came from the recognition of a RBP-J binding site in the pIX promoter [5]. Subsequently, adenovirus 13SE1A was shown to bind to RBP-J and to be capable of activating promoters containing RBP-J binding sites [174].

Therefore, EBV, KSHV, HPV, SV40 and adenovirus encode proteins that bind to RBP-J and mimic certain aspects of Notch signaling. In this way the virus can manipulate the ability of the Notch signaling pathway to influence proliferation and differentiation processes.

\section{Future perspectives}

Understanding how different Notch target genes are activated or repressed in different cell types still remains enigmatic. In our view, the key for understanding this problem is the composition of the RBP-J associated corepressor and coactivator complexes and the epigenetic status of the relevant Notch target gene. Switch-on and switch-off systems for Notch signaling are now needed to analyze the dynamic molecular mechanism(s) of transcriptional regulation.

Histone modifying enzymes, such as histone acetyltransferases and deacetylases (HDACs) as well as histone methylases and demethylases, have great potential in being drug targets; HDAC inhibitors are already used in clinical trials. Therefore, understanding the epigenetic regulatory mechanism controlling key Notch target genes could be translated into new therapeutic approaches, for example, in regard to leukemia.

Acknowledgements. We thank Dr. W. Schneiderhahn, Dr. P. Rodriguez, Dr. R. Liefke and X. Yue for critical reading of the manuscript. Research in the T.B. laboratory is supported by EmmyNoether fellowship of the DFG (BO-1639 and SFB592/C3) and the MPG. Research in the F.O. laboratory is supported by the DFG (SFB518/A18 and SFB497/B9).

1 Morgan, T. (1917) The theory of the gene. Am. Nat. 51, 513544.

2 Artavanis-Tsakonas, S., Rand, M.D. and Lake, R.J. (1999) Notch signaling: cell fate control and signal integration in development. Science 284, 770-776.

3 Fiuza, U.M. and Arias, A.M. (2007) Cell and molecular biology of Notch. J. Endocrinol. 194, 459-474.

4 Bray, S.J. (2006) Notch signalling: a simple pathway becomes complex. Nat. Rev. Mol. Cell Biol. 7, 678-689.

5 Dou, S., Zeng, X., Cortes, P., Erdjument-Bromage, H., Tempst, P., Honjo, T. and Vales, L.D. (1994) The recombination signal sequence-binding protein RBP-2N functions as a transcriptional repressor. Mol. Cell. Biol. 14, 3310-3319.

6 Waltzer, L., Bourillot, P.Y., Sergeant, A. and Manet, E. (1995) RBP-J kappa repression activity is mediated by a co-repressor and antagonized by the Epstein-Barr virus transcription factor EBNA2. Nucleic Acids Res. 23, 4939-4945.

7 Iso, T., Kedes, L. and Hamamori, Y. (2003) HES and HERP families: multiple effectors of the Notch signaling pathway. J. Cell. Physiol. 194, 237-255.

8 Fischer, A. and Gessler, M. (2007) Delta-Notch-and then? Protein interactions and proposed modes of repression by Hes and Hey bHLH factors. Nucleic Acids Res. 35, 4583-4596.

9 Bray, S. (1998) Notch signalling in Drosophila: three ways to use a pathway. Semin. Cell Dev. Biol. 9, 591-597.

10 Jarriault, S., Brou, C., Logeat, F., Schroeter, E.H., Kopan, R. and Israel, A. (1995) Signalling downstream of activated mammalian Notch. Nature 377, 355-358.

11 Nishimura, M., Isaka, F., Ishibashi, M., Tomita, K., Tsuda, H., Nakanishi, S. and Kageyama, R. (1998) Structure, chromosomal locus, and promoter of mouse Hes 2 gene, a homologue of Drosophila hairy and Enhancer of split. Genomics 49, 69-75.

12 Maier, M.M. and Gessler, M. (2000) Comparative analysis of the human and mouse Hey1 promoter: Hey genes are new Notch target genes. Biochem. Biophys. Res. Commun. 275, 652-660.

13 Iso, T., Sartorelli, V., Chung, G., Shichinohe, T., Kedes, L. and Hamamori, Y. (2001) HERP, a new primary target of Notch regulated by ligand binding. Mol. Cell. Biol. 21, 6071-6079.

14 Shawber, C., Nofziger, D., Hsieh, J.J., Lindsell, C., Bogler, O., Hayward, D. and Weinmaster, G. (1996) Notch signaling inhibits muscle cell differentiation through a CBF1-independent pathway. Development 122, 3765-3773.

15 Jarriault, S., Le Bail, O., Hirsinger, E., Pourquie, O., Logeat, F., Strong, C.F., Brou, C., Seidah, N.G. and Isra 1, A. (1998) 
Delta-1 activation of notch-1 signaling results in HES-1 transactivation. Mol. Cell. Biol. 18, 7423-7431.

16 Weng, A.P., Millholland, J.M., Yashiro-Ohtani, Y., Arcangeli, M.L., Lau, A., Wai, C., Del Bianco, C., Rodriguez, C.G., Sai, H., Tobias, J., Li, Y., Wolfe, M.S., Shachaf, C., Felsher, D. Blacklow, S.C., Pear, W.S. and Aster, J.C. (2006) c-Myc is an important direct target of Notch1 in T-cell acute lymphoblastic leukemia/lymphoma. Genes Dev. 20, 2096-2109.

17 Kageyama, R. and Ohtsuka, T. (1999) The Notch-Hes pathway in mammalian neural development. Cell Res. 9,179-188.

18 Kawamata, S., Du, C., Li, K. and Lavau, C. (2002) Overexpression of the Notch target genes Hes in vivo induces lymphoid and myeloid alterations. Oncogene 21,3855-3863.

19 Deftos, M.L., Huang, E., Ojala, E.W., Forbush, K.A. and Bevan, M.J. (2000) Notch1 signaling promotes the maturation of CD4 and CD8 SP thymocytes. Immunity 13, 73-84.

20 Reizis, B. and Leder, P. (2002) Direct induction of T lymphocyte-specific gene expression by the mammalian Notch signaling pathway. Genes Dev. 16, 295-300.

21 Fang, T.C., Yashiro-Ohtani, Y., Del Bianco, C., Knoblock, D.M., Blacklow, S.C. and Pear, W.S. (2007) Notch directly regulates Gata3 expression during $\mathrm{T}$ helper 2 cell differentiation. Immunity 27, 100-110.

22 Amsen, D., Antov, A., Jankovic, D., Sher, A., Radtke, F., Souabni, A., Busslinger, M., McCright, B., Gridley, T. and Flavell, R.A. (2007) Direct regulation of Gata3 expression determines the $\mathrm{T}$ helper differentiation potential of Notch. Immunity 27, 89-99.

23 Izon, D.J., Aster, J.C., He, Y., Weng, A., Karnell, F.G., Patriub, V., Xu, L., Bakkour, S., Rodriguez, C., Allman, D. and Pear, W.S. (2002) Deltex1 redirects lymphoid progenitors to the B cell lineage by antagonizing Notch1. Immunity 16 , 231-243.

24 Lamar, E., Deblandre, G., Wettstein, D., Gawantka, V., Pollet, N., Niehrs, C. and Kintner, C. (2001) Nrarp is a novel intracellular component of the Notch signaling pathway. Genes Dev. 15, 1885-1899.

25 Satoh, Y., Matsumura, I., Tanaka, H., Ezoe, S., Sugahara, H., Mizuki, M., Shibayama, H., Ishiko, E., Ishiko, J., Nakajima, K. and Kanakura, Y. (2004) Roles for c-Myc in self-renewal of hematopoietic stem cells. J. Biol. Chem. 279, 24986-24993.

26 Palomero, T., Lim, W.K., Odom, D.T., Sulis, M.L., Real, P.J., Margolin, A., Barnes, K.C., O’Neil, J., Neuberg, D., Weng, A.P., Aster, J.C., Sigaux, F., Soulier, J., Look, A.T., Young, R.A., Califano, A. and Ferrando, A.A. (2006) NOTCH1 directly regulates c-MYC and activates a feed-forward-loop transcriptional network promoting leukemic cell growth. Proc. Natl. Acad. Sci. USA 103, 18261-18266.

27 Ronchini, C. and Capobianco, A.J. (2001) Induction of cyclin D1 transcription and CDK2 activity by Notch(ic): implication for cell cycle disruption in transformation by Notch(ic). Mol. Cell. Biol. 21, 5925-5934.

28 Rangarajan, A., Talora, C., Okuyama, R., Nicolas, M., Mammucari, C., Oh, H., Aster, J.C., Krishna, S., Metzger, D., Chambon, P., Miele, L., Aguet, M., Radtke, F. and Dotto, G.P. (2001) Notch signaling is a direct determinant of keratinocyte growth arrest and entry into differentiation. EMBO J. 20, 3427-3436.

29 Oswald, F., Liptay, S., Adler, G. and Schmid, R.M. (1998) NFkappaB2 is a putative target gene of activated Notch-1 via RBP-Jkappa. Mol. Cell. Biol. 18, 2077-2088.

30 Deftos, M.L., He, Y.W., Ojala, E.W. and Bevan, M.J. (1998) Correlating notch signaling with thymocyte maturation. Immunity 9, 777-786.

31 Ordentlich, P., Lin, A., Shen, C.P., Blaumueller, C., Matsuno, K., Artavanis-Tsakonas, S. and Kadesch, T. (1998) Notch inhibition of E47 supports the existence of a novel signaling pathway. Mol. Cell. Biol. 18, 2230-2239.

32 Weerkamp, F., Luis, T.C., Naber, B.A., Koster, E.E., Jeannotte, L., van Dongen, J.J. and Staal, F.J. (2006) Identification of Notch target genes in uncommitted T-cell progenitors: No direct induction of a T-cell specific gene program. Leukemia 20, 1967-1977.

33 Olave, I., Reinberg, D. and Vales, L.D. (1998) The mammalian transcriptional repressor RBP (CBF1) targets TFIID and TFIIA to prevent activated transcription. Genes Dev. 12, $1621-1637$.

34 Kao, H.Y., Ordentlich, P., Koyano-Nakagawa, N., Tang, Z., Downes, M., Kintner, C.R., Evans, R.M. and Kadesch, T. (1998) A histone deacetylase corepressor complex regulates the Notch signal transduction pathway. Genes Dev. 12, 22692277.

35 Hsieh, J.J., Zhou, S., Chen, L., Young, D.B. and Hayward, S.D. (1999) CIR, a corepressor linking the DNA binding factor CBF1 to the histone deacetylase complex. Proc. Natl. Acad. Sci. USA 96, 23-28.

36 Oswald, F., Winkler, M., Cao, Y., Astrahantseff, K., Bourteele, S., Knochel, W. and Borggrefe, T. (2005) RBP-Jkappa/ SHARP recruits CtIP/CtBP corepressors to silence Notch target genes. Mol. Cell. Biol. 25, 10379-10390.

37 Morel, V., Lecourtois, M., Massiani, O., Maier, D., Preiss, A. and Schweisguth, F. (2001) Transcriptional repression by suppressor of hairless involves the binding of a hairless-dCtBP complex in Drosophila. Curr. Biol. 11, 789-792.

38 Barolo, S., Stone, T., Bang, A.G. and Posakony, J.W. (2002) Default repression and Notch signaling: Hairless acts as an adaptor to recruit the corepressors Groucho and dCtBP to Suppressor of Hairless. Genes Dev. 16, 1964-1976.

39 Hildebrand, J.D. and Soriano, P. (2002) Overlapping and unique roles for $\mathrm{C}$-terminal binding protein 1 (CtBP1) and CtBP2 during mouse development. Mol. Cell. Biol. 22, 52965307.

40 Shi, Y., Sawada, J., Sui, G., Affar el, B., Whetstine, J.R., Lan, F., Ogawa, H., Luke, M.P., Nakatani, Y. and Shi, Y. (2003) Coordinated histone modifications mediated by a CtBP corepressor complex. Nature 422, 735-738.

41 Kouzarides, T. (2007) Chromatin modifications and their function. Cell 128, 693-705.

42 Shahbazian, M.D. and Grunstein, M. (2007) Functions of sitespecific histone acetylation and deacetylation. Annu. Rev. Biochem. 76, 75-100.

43 Shi, Y. and Whetstine, J.R. (2007) Dynamic regulation of histone lysine methylation by demethylases. Mol. Cell 25, 114.

44 Schneider, R. and Grosschedl, R. (2007) Dynamics and interplay of nuclear architecture, genome organization, and gene expression. Genes Dev. 21, 3027-3043.

45 Oswald, F., Tauber, B., Dobner, T., Bourteele, S., Kostezka, U., Adler, G., Liptay, S. and Schmid, R.M. (2001) p300 acts as a transcriptional coactivator for mammalian Notch-1. Mol. Cell. Biol. 21, 7761-7774.

46 Wallberg, A.E., Pedersen, K., Lendahl, U. and Roeder, R.G. (2002) p300 and PCAF act cooperatively to mediate transcriptional activation from chromatin templates by notch intracellular domains in vitro. Mol. Cell. Biol. 22, 7812-7819.

47 Kurooka, H. and Honjo, T. (2000) Functional interaction between the mouse notch 1 intracellular region and histone acetyltransferases PCAF and GCN5. J. Biol. Chem. 275, $17211-17220$

48 Oswald, F., Kostezka, U., Astrahantseff, K., Bourteele, S., Dillinger, K., Zechner, U., Ludwig, L., Wilda, M., Hameister, H., Knochel, W., Liptay, S. and Schmid, R.M. (2002) SHARP is a novel component of the Notch/RBP-Jkappa signalling pathway. EMBO J. 21, 5417-5426.

49 Krejci, A. and Bray, S. (2007) Notch activation stimulates transient and selective binding of $\mathrm{Su}(\mathrm{H}) / \mathrm{CSL}$ to target enhancers. Genes Dev. 21, 1322-1327.

50 Bray, S., Musisi, H. and Bienz, M. (2005) Bre1 is required for Notch signaling and histone modification. Dev. Cell 8, $279-$ 286.

51 Wang, J., Scully, K., Zhu, X., Cai, L., Zhang, J., Prefontaine, G.G., Krones, A., Ohgi, K.A., Zhu, P., Garcia-Bassets, I., Liu, F., Taylor, H., Lozach, J., Jayes, F.L., Korach, K.S., Glass, 
C.K., Fu, X.D. and Rosenfeld, M.G. (2007) Opposing LSD1 complexes function in developmental gene activation and repression programmes. Nature 446, $882-887$.

52 Smialowska, A. and Baumeister, R. (2006) Presenilin function in Caenorhabditis elegans. Neurodegener. Dis. 3, 227-232.

53 Nagel, A.C., Krejci, A., Tenin, G., Bravo-Patino, A., Bray, S. Maier, D. and Preiss, A. (2005) Hairless-mediated repression of notch target genes requires the combined activity of Groucho and CtBP corepressors. Mol. Cell. Biol. 25, $10433-$ 10441.

54 Qin, H., Wang, J., Liang, Y., Taniguchi, Y., Tanigaki, K. and Han, H. (2004) RING1 inhibits transactivation of RBP-J by Notch through interaction with LIM protein KyoT2. Nucleic Acids Res. 32, 1492-1501.

55 Bracken, A.P., Dietrich, N., Pasini, D., Hansen, K.H. and Helin, K. (2006) Genome-wide mapping of Polycomb target genes unravels their roles in cell fate transitions. Genes Dev. 20, 1123-1136.

56 Hsu, K.W., Hsieh, R.H., Wu Lee, Y.H., Chao, C.H., Wu, K.J., Tseng, M.J. and Yeh, T.S. (2008) The activated Notch1 receptor cooperates with \{alpha\}-enolase and MBP-1 in modulating c-myc activity. Mol. Cell. Biol.

57 Ferres-Marco, D., Gutierrez-Garcia, I., Vallejo, D.M., Bolivar, J., Gutierrez-Avino, F.J. and Dominguez, M. (2006) Epigenetic silencers and Notch collaborate to promote malignant tumours by Rb silencing. Nature 439, 430-436.

58 Goodfellow, H., Krejci, A., Moshkin, Y., Verrijzer, C.P. Karch, F. and Bray, S.J. (2007) Gene-specific targeting of the histone chaperone asf1 to mediate silencing. Dev. Cell 13, 593-600.

59 Hamaguchi, Y., Matsunami, N., Yamamoto, Y. and Honjo, T. (1989) Purification and characterization of a protein that binds to the recombination signal sequence of the immunoglobulin J kappa segment. Nucleic Acids Res. 17, 9015-9026.

60 Brou, C., Logeat, F., Lecourtois, M., Vandekerckhove, J. Kourilsky, P., Schweisguth, F. and Israel, A. (1994) Inhibition of the DNA-binding activity of Drosophila suppressor of hairless and of its human homolog, KBF2/RBP-J kappa, by direct protein-protein interaction with Drosophila hairless. Genes Dev. 8, 2491-2503.

61 Ling, P.D., Rawlins, D.R. and Hayward, S.D. (1993) The Epstein-Barr virus immortalizing protein EBNA-2 is targeted to DNA by a cellular enhancer-binding protein. Proc. Natl. Acad. Sci. USA 90, 9237-9241.

62 Furukawa, T., Kawaichi, M., Matsunami, N., Ryo, H. Nishida, Y. and Honjo, T. (1991) The Drosophila RBP-J kappa gene encodes the binding protein for the immunoglobulin J kappa recombination signal sequence. J. Biol. Chem. 266, 23334-23340.

63 Christensen, S., Kodoyianni, V., Bosenberg, M., Friedman, L. and Kimble, J. (1996) lag-1, a gene required for lin-12 and glp1 signaling in Caenorhabditis elegans, is homologous to human CBF1 and Drosophila $\mathrm{Su}(\mathrm{H})$. Development 122 , $1373-1383$.

64 Tun, T., Hamaguchi, Y., Matsunami, N., Furukawa, T., Honjo, T. and Kawaichi, M. (1994) Recognition sequence of a highly conserved DNA binding protein RBP-J kappa. Nucleic Acids Res. 22, 965-971.

65 Minoguchi, S., Taniguchi, Y., Kato, H., Okazaki, T., Strobl, L.J., Zimber-Strobl, U., Bornkamm, G.W. and Honjo, T. (1997) RBP-L, a transcription factor related to RBP-Jkappa. Mol. Cell. Biol. 17, 2679-2687.

66 Beres, T.M., Masui, T., Swift, G.H., Shi, L., Henke, R.M. and MacDonald, R.J. (2006) PTF1 is an organ-specific and Notchindependent basic helix-loop-helix complex containing the mammalian Suppressor of Hairless (RBP-J) or its paralogue, RBP-L. Mol. Cell. Biol. 26, 117-130.

67 Oka, C., Nakano, T., Wakeham, A., de la Pompa, J.L., Mori, C., Sakai, T., Okazaki, S., Kawaichi, M., Shiota, K., Mak, T.W. and Honjo, T. (1995) Disruption of the mouse RBP-J kappa gene results in early embryonic death. Development 121 , $3291-3301$.
68 Han, H., Tanigaki, K., Yamamoto, N., Kuroda, K., Yoshimoto, M., Nakahata, T., Ikuta, K. and Honjo, T. (2002) Inducible gene knockout of transcription factor recombination signal binding protein- $\mathrm{J}$ reveals its essential role in $\mathrm{T}$ versus $\mathrm{B}$ lineage decision. Int. Immunol. 14, 637-645.

69 Zhou, S., Fujimuro, M., Hsieh, J.J., Chen, L., Miyamoto, A., Weinmaster, G. and Hayward, S.D. (2000) SKIP, a CBF1associated protein, interacts with the ankyrin repeat domain of NotchIC To facilitate NotchIC function. Mol. Cell. Biol. 20, 2400-2410.

70 Zhou, S., Fujimuro, M., Hsieh, J.J., Chen, L. and Hayward, S.D. (2000) A role for SKIP in EBNA2 activation of CBF1repressed promoters. J. Virol. 74, 1939-1947.

71 Fryer, C.J., White, J.B. and Jones, K.A. (2004) Mastermind recruits $\mathrm{CycC}: \mathrm{CDK} 8$ to phosphorylate the Notch ICD and coordinate activation with turnover. Mol. Cell 16, 509-520.

72 Eimer, S., Lakowski, B., Donhauser, R. and Baumeister, R. (2002) Loss of spr-5 bypasses the requirement for the C.elegans presenilin sel-12 by derepressing hop-1. EMBO J. 21, 5787-5796.

73 Taniguchi, Y., Furukawa, T., Tun, T., Han, H. and Honjo, T. (1998) LIM protein KyoT2 negatively regulates transcription by association with the RBP-J DNA-binding protein. Mol. Cell. Biol. 18, 644-654.

74 Qin, H., Du, D., Zhu, Y., Li, J., Feng, L., Liang, Y. and Han, H. (2005) The PcG protein HPC2 inhibits RBP-J-mediated transcription by interacting with LIM protein KyoT2. FEBS Lett. 579, 1220-1226.

75 Shi, Y., Downes, M., Xie, W., Kao, H.Y., Ordentlich, P., Tsai, C.C., Hon, M. and Evans, R.M. (2001) Sharp, an inducible cofactor that integrates nuclear receptor repression and activation. Genes Dev. 15, 1140-1151.

76 Kuang, B., Wu, S.C., Shin, Y., Luo, L. and Kolodziej, P. (2000) split ends encodes large nuclear proteins that regulate neuronal cell fate and axon extension in the Drosophila embryo. Development 127, 1517-1529.

77 Sanchez-Pulido, L., Rojas, A.M., van Wely, K.H., Martinez, A.C. and Valencia, A. (2004) SPOC: a widely distributed domain associated with cancer, apoptosis and transcription. BMC Bioinformatics 5, 91.

78 Salat, D., Liefke, R., Wiedenmann, J., Borggrefe, T. and Oswald, F. (2008) ETO, but not leukemogenic fusion protein AML1/ETO, augments RBP-Jkappa/SHARP-mediated repression of notch target genes. Mol. Cell. Biol. 28, 3502-3512.

79 Ariyoshi, M. and Schwabe, J.W. (2003) A conserved structural motif reveals the essential transcriptional repression function of Spen proteins and their role in developmental signaling. Genes Dev. 17, 1909-1920.

80 Li, J., Li, J., Yang, X., Qin, H., Zhou, P., Liang, Y. and Han, H. (2005) The C terminus of MINT forms homodimers and abrogates MINT-mediated transcriptional repression. Biochim. Biophys. Acta 1729, 50-56.

81 Newberry, E.P., Latifi, T. and Towler, D.A. (1999) The RRM domain of MINT, a novel Msx2 binding protein, recognizes and regulates the rat osteocalcin promoter. Biochemistry (Mosc.) 38, 10678-10690.

82 Kuroda, K., Han, H., Tani, S., Tanigaki, K., Tun, T., Furukawa, T., Taniguchi, Y., Kurooka, H., Hamada, Y., Toyokuni, S. and Honjo, T. (2003) Regulation of marginal zone B cell development by MINT, a suppressor of Notch/ RBP-J signaling pathway. Immunity 18, 301-312.

83 Yabe, D., Fukuda, H., Aoki, M., Yamada, S., Takebayashi, S., Shinkura, R., Yamamoto, N. and Honjo, T. (2007) Generation of a conditional knockout allele for mammalian Spen protein Mint/SHARP. Genesis 45, 300-306.

84 Tsuji, M., Shinkura, R., Kuroda, K., Yabe, D. and Honjo, T. (2007) Msx2-interacting nuclear target protein (Mint) deficiency reveals negative regulation of early thymocyte differentiation by Notch/RBP-J signaling. Proc. Natl. Acad. Sci. USA 104, 1610-1615.

85 Maier, D. (2006) Hairless: the ignored antagonist of the Notch signalling pathway. Hereditas 143, 212-221. 
86 Mercher, T., Coniat, M.B., Monni, R., Mauchauffe, M. Nguyen Khac, F., Gressin, L., Mugneret, F., Leblanc, T., Dastugue, N., Berger, R. and Bernard, O.A. (2001) Involvement of a human gene related to the Drosophila spen gene in the recurrent $t(1 ; 22)$ translocation of acute megakaryocytic leukemia. Proc. Natl. Acad. Sci. USA 98, 5776-5779.

87 Ma, Z., Morris, S.W., Valentine, V., Li, M., Herbrick, J.A., Cui, X., Bouman, D., Li, Y., Mehta, P.K., Nizetic, D., Kaneko, Y., Chan, G.C., Chan, L.C., Squire, J., Scherer, S.W. and Hitzler, J.K. (2001) Fusion of two novel genes, RBM15 and MKL1, in the $\mathrm{t}(1 ; 22)(\mathrm{p} 13 ; \mathrm{q} 13)$ of acute megakaryoblastic leukemia. Nat. Genet. 28, 220-221.

88 Ma, X., Renda, M.J., Wang, L., Cheng, E.C., Niu, C., Morris, S.W., Chi, A.S. and Krause, D.S. (2007) Rbm15 modulates Notch-induced transcriptional activation and affects myeloid differentiation. Mol. Cell. Biol. 27, 3056-3064.

89 Raffel, G.D., Mercher, T., Shigematsu, H., Williams, I.R., Cullen, D.E., Akashi, K., Bernard, O.A. and Gilliland, D.G. (2007) Ott1(Rbm15) has pleiotropic roles in hematopoietic development. Proc. Natl. Acad. Sci. USA 104, 6001-6006.

90 Zhou, Z., Licklider, L.J., Gygi, S.P. and Reed, R. (2002) Comprehensive proteomic analysis of the human spliceosome. Nature 419, 182-185.

91 Hiriart, E., Gruffat, H., Buisson, M., Mikaelian, I., Keppler, S., Meresse, P., Mercher, T., Bernard, O.A., Sergeant, A. and Manet, E. (2005) Interaction of the Epstein-Barr virus mRNA export factor EB2 with human Spen proteins SHARP, OTT1, and a novel member of the family, OTT3, links Spen proteins with splicing regulation and mRNA export. J. Biol. Chem. 280, 36935-36945.

92 Alcalay, M., Meani, N., Gelmetti, V., Fantozzi, A., Fagioli, M., Orleth, A., Riganelli, D., Sebastiani, C., Cappelli, E., Casciari, C., Sciurpi, M.T., Mariano, A.R., Minardi, S.P., Luzi, L., Muller, H., Di Fiore, P.P., Frosina, G. and Pelicci, P.G. (2003) Acute myeloid leukemia fusion proteins deregulate genes involved in stem cell maintenance and DNA repair. J. Clin. Invest. 112, 1751-1761.

93 Radtke, F., Schweisguth, F. and Pear, W. (2005) The Notch 'gospel'. EMBO Rep. 6, 1120-1125.

94 Tamura, K., Taniguchi, Y., Minoguchi, S., Sakai, T., Tun, T., Furukawa, T. and Honjo, T. (1995) Physical interaction between a novel domain of the receptor Notch and the transcription factor RBP-J kappa/Su(H). Curr. Biol. 5, 1416 1423.

95 Wharton, K.A., Yedvobnick, B., Finnerty, V.G. and Artavanis-Tsakonas, S. (1985) opa: a novel family of transcribed repeats shared by the Notch locus and other developmentally regulated loci in D. melanogaster. Cell 40, 55-62.

96 Hsieh, J.J., Henkel, T., Salmon, P., Robey, E., Peterson, M.G. and Hayward, S.D. (1996) Truncated mammalian Notch1 activates CBF1/RBPJk-repressed genes by a mechanism resembling that of Epstein-Barr virus EBNA2. Mol. Cell. Biol. 16, 952-959.

97 Kurooka, H., Kuroda, K. and Honjo, T. (1998) Roles of the ankyrin repeats and C-terminal region of the mouse notch intracellular region. Nucleic Acids Res. 26, 5448-5455.

98 Le Gall, M. and Giniger, E. (2004) Identification of two binding regions for the suppressor of hairless protein within the intracellular domain of Drosophila notch. J. Biol. Chem. 279, 29418-29426.

99 Shaye, D.D. and Greenwald, I. (2005) LIN-12/Notch trafficking and regulation of DSL ligand activity during vulval induction in Caenorhabditis elegans. Development 132 5081-5092.

100 Aster, J.C., Pear, W.S. and Blacklow, S.C. (2008) Notch signaling in leukemia. Annu. Rev. Pathol. 3, 587-613.

101 Petcherski, A.G. and Kimble, J. (2000) Mastermind is a putative activator for Notch. Curr. Biol. 10, R471-473.

102 Wu, L., Aster, J.C., Blacklow, S.C., Lake, R., ArtavanisTsakonas, S. and Griffin, J.D. (2000) MAML1, a human homologue of Drosophila mastermind, is a transcriptional coactivator for NOTCH receptors. Nat. Genet. 26, 484-489.
103 Nam, Y., Sliz, P., Song, L., Aster, J.C. and Blacklow, S.C. (2006) Structural basis for cooperativity in recruitment of MAML coactivators to Notch transcription complexes. Cell 124, 973-983.

104 Kovall, R.A. (2007) Structures of CSL, Notch and Mastermind proteins: piecing together an active transcription complex. Curr. Opin. Struct. Biol. 17, 117-127.

105 Kovall, R.A. (2008) More complicated than it looks: assembly of Notch pathway transcription complexes. Oncogene 27, 5099-5109.

106 Maillard, I., Weng, A.P., Carpenter, A.C., Rodriguez, C.G., Sai, H., Xu, L., Allman, D., Aster, J.C. and Pear, W.S. (2004) Mastermind critically regulates Notch-mediated lymphoid cell fate decisions. Blood 104, 1696-1702.

107 Maillard, I., Fang, T. and Pear, W.S. (2005) Regulation of lymphoid development, differentiation, and function by the Notch pathway. Annu. Rev. Immunol. 23, 945-974.

108 Saint Just Ribeiro, M., Hansson, M.L. and Wallberg, A.E. (2007) A proline repeat domain in the Notch co-activator MAML1 is important for the p300-mediated acetylation of MAML1. Biochem. J. 404, 289-298.

109 Jeffries, S., Robbins, D.J. and Capobianco, A.J. (2002) Characterization of a high-molecular-weight Notch complex in the nucleus of Notch(ic)-transformed RKE cells and in a human T-cell leukemia cell line. Mol. Cell. Biol. 22, 39273941.

110 Kovall, R.A. and Hendrickson, W.A. (2004) Crystal structure of the nuclear effector of Notch signaling, CSL, bound to DNA. EMBO J. 23, 3441-3451.

111 Wilson, J.J. and Kovall, R.A. (2006) Crystal structure of the CSL-Notch-Mastermind ternary complex bound to DNA. Cell 124, 985-996.

112 Pirot, P., van Grunsven, L.A., Marine, J.C., Huylebroeck, D. and Bellefroid, E.J. (2004) Direct regulation of the Nrarp gene promoter by the Notch signaling pathway. Biochem. Biophys. Res. Commun. 322, 526-534.

113 Krebs, L.T., Deftos, M.L., Bevan, M.J. and Gridley, T. (2001) The Nrarp gene encodes an ankyrin-repeat protein that is transcriptionally regulated by the notch signaling pathway. Dev. Biol. 238, 110-119.

114 Yun, T.J. and Bevan, M.J. (2003) Notch-regulated ankyrinrepeat protein inhibits Notch1 signaling: multiple Notch1 signaling pathways involved in $\mathrm{T}$ cell development. J. Immunol. 170, 5834-5841.

115 Yamamoto, N., Yamamoto, S., Inagaki, F., Kawaichi, M., Fukamizu, A., Kishi, N., Matsuno, K., Nakamura, K., Weinmaster, G., Okano, H. and Nakafuku, M. (2001) Role of Deltex-1 as a transcriptional regulator downstream of the Notch receptor. J. Biol. Chem. 276, 45031-45040.

116 Lehar, S.M. and Bevan, M.J. (2006) T cells develop normally in the absence of both Deltex1 and Deltex2. Mol. Cell. Biol. 26, 7358-7371.

117 Chiang, M.Y., Xu, M.L., Histen, G., Shestova, O., Roy, M., Nam, Y., Blacklow, S.C., Sacks, D.B., Pear, W.S. and Aster, J.C. (2006) Identification of a conserved negative regulatory sequence that influences the leukemogenic activity of NOTCH1. Mol. Cell. Biol. 26, 6261-6271.

118 Parks, A.L., Huppert, S.S. and Muskavitch, M.A. (1997) The dynamics of neurogenic signalling underlying bristle development in Drosophila melanogaster. Mech. Dev. 63, 61-74.

119 Lai, E.C. (2004) Notch signaling: control of cell communication and cell fate. Development 131, 965-973.

120 Lutolf, S., Radtke, F., Aguet, M., Suter, U. and Taylor, V. (2002) Notch1 is required for neuronal and glial differentiation in the cerebellum. Development 129, 373-385.

121 Mizutani, K., Yoon, K., Dang, L., Tokunaga, A. and Gaiano, N. (2007) Differential Notch signalling distinguishes neural stem cells from intermediate progenitors. Nature 449, 351355.

122 Basak, O. and Taylor, V. (2007) Identification of selfreplicating multipotent progenitors in the embryonic nervous 
system by high Notch activity and Hes5 expression. Eur. J. Neurosci. 25, 1006-1022.

123 Koch, U. and Radtke, F. (2007) Notch and cancer: a doubleedged sword. Cell. Mol. Life Sci. 64, 2746-2762.

124 van Es, J.H., van Gijn, M.E., Riccio, O., van den Born, M. Vooijs, M., Begthel, H., Cozijnsen, M., Robine, S., Winton, D.J., Radtke, F. and Clevers, H. (2005) Notch/gammasecretase inhibition turns proliferative cells in intestinal crypts and adenomas into goblet cells. Nature 435, 959-963.

125 Fre, S., Huyghe, M., Mourikis, P., Robine, S., Louvard, D. and Artavanis-Tsakonas, S. (2005) Notch signals control the fate of immature progenitor cells in the intestine. Nature 435, $964-$ 968.

126 Wong, G.T., Manfra, D., Poulet, F.M., Zhang, Q., Josien, H., Bara, T., Engstrom, L., Pinzon-Ortiz, M., Fine, J.S., Lee, H.J., Zhang, L., Higgins, G.A. and Parker, E.M. (2004) Chronic treatment with the gamma-secretase inhibitor LY-411,575 inhibits beta-amyloid peptide production and alters lymphopoiesis and intestinal cell differentiation. J. Biol. Chem. 279, 12876-12882.

127 Wilson, A. and Radtke, F. (2006) Multiple functions of Notch signaling in self-renewing organs and cancer. FEBS Lett. 580, $2860-2868$.

128 Okuyama, R., Tagami, H. and Aiba, S. (2008) Notch signaling: its role in epidermal homeostasis and in the pathogenesis of skin diseases. J. Dermatol. Sci. 49, 187-194.

129 Kumano, K., Chiba, S., Kunisato, A., Sata, M., Saito, T., Nakagami-Yamaguchi, E., Yamaguchi, T., Masuda, S., Shimizu, K., Takahashi, T., Ogawa, S., Hamada, Y. and Hirai, H. (2003) Notch1 but not Notch2 is essential for generating hematopoietic stem cells from endothelial cells. Immunity 18, $699-711$.

130 Robert-Moreno, A., Espinosa, L., de la Pompa, J.L. and Bigas, A. (2005) RBPjkappa-dependent Notch function regulates Gata2 and is essential for the formation of intraembryonic hematopoietic cells. Development 132, 11171126.

131 Tsai, F.Y., Keller, G., Kuo, F.C., Weiss, M., Chen, J., Rosenblatt, M., Alt, F.W. and Orkin, S.H. (1994) An early haematopoietic defect in mice lacking the transcription factor GATA-2. Nature 371, 221-226.

132 Suzuki, T. and Chiba, S. (2005) Notch signaling in hematopoietic stem cells. Int. J. Hematol. 82, 285-294.

133 Duncan, A.W., Rattis, F.M., DiMascio, L.N., Congdon, K.L., Pazianos, G., Zhao, C., Yoon, K., Cook, J.M., Willert, K., Gaiano, N. and Reya, T. (2005) Integration of Notch and Wnt signaling in hematopoietic stem cell maintenance. Nat. Immunol. 6, 314-322.

134 Radtke, F., Wilson, A., Stark, G., Bauer, M., van Meerwijk, J., MacDonald, H.R. and Aguet, M. (1999) Deficient T cell fate specification in mice with an induced inactivation of Notch1. Immunity 10, 547-558.

135 Mancini, S.J., Mantei, N., Dumortier, A., Suter, U., MacDonald, H.R. and Radtke, F. (2005) Jagged1-dependent Notch signaling is dispensable for hematopoietic stem cell self-renewal and differentiation. Blood 105, 2340-2342.

136 Maillard, I., Koch, U. Dumortier, A., Shestova, O., Xu, L., Sai, H., Pross, S.E., Aster, J.C., Bhandoola, A., Radtke, F., Pear, W.S. (2008) Canonical Notch signaling is dispensable for the maintenance of adult hematopoietic stem cells. Cell Stem Cell, Vol. 2, pp. 356-366.

137 Pui, J.C., Allman, D., Xu, L., DeRocco, S., Karnell, F.G., Bakkour, S., Lee, J.Y., Kadesch, T., Hardy, R.R., Aster, J.C. and Pear, W.S. (1999) Notch1 expression in early lymphopoiesis influences $\mathrm{B}$ versus $\mathrm{T}$ lineage determination. Immunity 11, 299-308.

138 Dorsch, M., Zheng, G., Yowe, D., Rao, P., Wang, Y., Shen, Q., Murphy, C., Xiong, X., Shi, Q., Gutierrez-Ramos, J.C., Fraser, C. and Villeval, J.L. (2002) Ectopic expression of Delta4 impairs hematopoietic development and leads to lymphoproliferative disease. Blood 100, 2046-2055.
139 Schmitt, T.M. and Zuniga-Pflucker, J.C. (2002) Induction of T cell development from hematopoietic progenitor cells by delta-like-1 in vitro. Immunity 17, 749-756.

140 Tanigaki, K. and Honjo, T. (2007) Regulation of lymphocyte development by Notch signaling. Nat. Immunol. 8, 451-456.

141 Osborne, B.A. and Minter, L.M. (2007) Notch signalling during peripheral T-cell activation and differentiation. Nat. Rev. Immunol. 7, 64-75.

142 Roessler, S. and Grosschedl, R. (2006) Role of transcription factors in commitment and differentiation of early B lymphoid cells. Semin. Immunol. 18, 12-19.

143 Tanigaki, K., Kuroda, K., Han, H. and Honjo, T. (2003) Regulation of B cell development by Notch/RBP-J signaling. Semin. Immunol. 15, 113-119.

144 Santos, M.A., Sarmento, L.M., Rebelo, M., Doce, A.A., Maillard, I., Dumortier, A., Neves, H., Radtke, F., Pear, W.S., Parreira, L. and Demengeot, J. (2007) Notch1 engagement by Delta-like-1 promotes differentiation of B lymphocytes to antibody-secreting cells. Proc. Natl. Acad. Sci. USA 104, 15454-15459.

145 Thomas, M., Calamito, M., Srivastava, B., Maillard, I., Pear, W.S. and Allman, D. (2007) Notch activity synergizes with Bcell-receptor and CD40 signaling to enhance B-cell activation. Blood 109, 3342-3350.

146 Robert-Moreno, A., Espinosa, L., Sanchez, M.J., de la Pompa, J.L. and Bigas, A. (2007) The notch pathway positively regulates programmed cell death during erythroid differentiation. Leukemia 21, 1496-1503.

147 Milner, L.A., Bigas, A., Kopan, R., Brashem-Stein, C., Bernstein, I.D. and Martin, D.I. (1996) Inhibition of granulocytic differentiation by mNotch1. Proc. Natl. Acad. Sci. USA 93, 13014-13019.

148 Bigas, A., Martin, D.I. and Milner, L.A. (1998) Notch1 and Notch2 inhibit myeloid differentiation in response to different cytokines. Mol. Cell. Biol. 18, 2324-2333.

149 Ohishi, K., Varnum-Finney, B., Serda, R.E., Anasetti, C. and Bernstein, I.D. (2001) The Notch ligand, Delta-1, inhibits the differentiation of monocytes into macrophages but permits their differentiation into dendritic cells. Blood 98, 1402-1407.

150 Zhou, L., Li, L.W., Yan, Q., Petryniak, B., Man, Y., Su, C., Shim, J., Chervin, S. and Lowe, J.B. (2008) Notch-dependent control of myelopoiesis is regulated by fucosylation. Blood $112,308-319$.

151 Schroeder, T. and Just, U. (2000) Notch signalling via RBP-J promotes myeloid differentiation. EMBO J. 19, 2558-2568.

152 Radtke, F., Ferrero, I., Wilson, A., Lees, R., Aguet, M. and MacDonald, H.R. (2000) Notch1 deficiency dissociates the intrathymic development of dendritic cells and T cells. J. Exp. Med. 191, 1085-1094.

153 Rothenberg, E.V., Moore, J.E. and Yui, M.A. (2008) Launching the T-cell-lineage developmental programme. Nat. Rev. Immunol. 8, 9-21.

154 Radtke, F., Wilson, A. and MacDonald, H.R. (2005) Notch signaling in hematopoiesis and lymphopoiesis: lessons from Drosophila. Bioessays 27, 1117-1128.

155 Roy, M., Pear, W.S. and Aster, J.C. (2007) The multifaceted role of Notch in cancer. Curr. Opin. Genet. Dev. 17, 52-59.

156 Jhappan, C., Gallahan, D., Stahle, C., Chu, E., Smith, G.H., Merlino, G. and Callahan, R. (1992) Expression of an activated Notch-related int-3 transgene interferes with cell differentiation and induces neoplastic transformation in mammary and salivary glands. Genes Dev. 6, 345-355.

157 Ellisen, L.W., Bird, J., West, D.C., Soreng, A.L., Reynolds, T.C., Smith, S.D. and Sklar, J. (1991) TAN-1, the human homolog of the Drosophila notch gene, is broken by chromosomal translocations in $\mathrm{T}$ lymphoblastic neoplasms. Cell 66, 649-661.

158 Pear, W.S., Aster, J.C., Scott, M.L., Hasserjian, R.P., Soffer, B., Sklar, J. and Baltimore, D. (1996) Exclusive development of $\mathrm{T}$ cell neoplasms in mice transplanted with bone marrow expressing activated Notch alleles. J. Exp. Med. 183, 22832291. 
159 Weng, A.P., Ferrando, A.A., Lee, W., Morris, J.P.t., Silverman, L.B., Sanchez-Irizarry, C., Blacklow, S.C., Look, A.T. and Aster, J.C. (2004) Activating mutations of NOTCH1 in human $\mathrm{T}$ cell acute lymphoblastic leukemia. Science 306, 269-271.

160 Aster, J.C. (2005) Deregulated NOTCH signaling in acute Tcell lymphoblastic leukemia/lymphoma: new insights, questions, and opportunities. Int. J. Hematol. 82, 295-301.

161 van Vlierberghe, P., Meijerink, J.P., Lee, C., Ferrando, A.A., Look, A.T., van Wering, E.R., Beverloo, H.B., Aster, J.C. and Pieters, R. (2006) A new recurrent 9q34 duplication in pediatric T-cell acute lymphoblastic leukemia. Leukemia 20, $1245-1253$.

162 Girard, L., Hanna, Z., Beaulieu, N., Hoemann, C.D., Simard, C., Kozak, C.A. and Jolicoeur, P. (1996) Frequent provirus insertional mutagenesis of Notch1 in thymomas of MMTVD/ myc transgenic mice suggests a collaboration of c-myc and Notch1 for oncogenesis. Genes Dev. 10, 1930-1944.

163 Feldman, B.J., Hampton, T. and Cleary, M.L. (2000) A carboxy-terminal deletion mutant of Notch1 accelerates lymphoid oncogenesis in E2A-PBX1 transgenic mice. Blood 96, 1906-1913.

164 Beverly, L.J. and Capobianco, A.J. (2003) Perturbation of Ikaros isoform selection by MLV integration is a cooperative event in Notch(IC)-induced T cell leukemogenesis. Cancer Cell 3, 551-564.

165 Bellavia, D., Campese, A.F., Checquolo, S., Balestri, A., Biondi, A., Cazzaniga, G., Lendahl, U., Fehling, H.J., Hayday, A.C., Frati, L., von Boehmer, H., Gulino, A. and Screpanti, I (2002) Combined expression of pTalpha and Notch 3 in T cell leukemia identifies the requirement of preTCR for leukemogenesis. Proc. Natl. Acad. Sci. USA 99, 3788-3793.

166 Zimber-Strobl, U. and Strobl, L.J. (2001) EBNA2 and Notch signalling in Epstein-Barr virus mediated immortalization of B lymphocytes. Semin. Cancer Biol. 11, 423-434.
167 Cohen, J.I., Wang, F., Mannick, J. and Kieff, E. (1989) Epstein-Barr virus nuclear protein 2 is a key determinant of lymphocyte transformation. Proc. Natl. Acad. Sci. USA 86, 9558-9562.

168 Hammerschmidt, W., Sugden, B. and Baichwal, V.R. (1989) The transforming domain alone of the latent membrane protein of Epstein-Barr virus is toxic to cells when expressed at high levels. J. Virol. 63, 2469-2475.

169 Zimber-Strobl, U., Strobl, L.J., Meitinger, C., Hinrichs, R., Sakai, T., Furukawa, T., Honjo, T. and Bornkamm, G.W. (1994) Epstein-Barr virus nuclear antigen 2 exerts its transactivating function through interaction with recombination signal binding protein RBP-J kappa, the homologue of Drosophila Suppressor of Hairless. EMBO J. 13, 4973-4982.

170 Henkel, T., Ling, P.D., Hayward, S.D. and Peterson, M.G. (1994) Mediation of Epstein-Barr virus EBNA2 transactivation by recombination signal-binding protein $\mathrm{J}$ kappa. Science 265, 92-95.

171 Yalamanchili, R., Tong, X., Grossman, S., Johannsen, E., Mosialos, G. and Kieff, E. (1994) Genetic and biochemical evidence that EBNA 2 interaction with a $63-\mathrm{kDa}$ cellular GTG-binding protein is essential for B lymphocyte growth transformation by EBV. Virology 204, 634-641.

172 Liang, Y., Chang, J., Lynch, S.J., Lukac, D.M. and Ganem, D. (2002) The lytic switch protein of KSHV activates gene expression via functional interaction with RBP-Jkappa (CSL), the target of the Notch signaling pathway. Genes Dev. 16, 1977-1989.

173 Hayward, S.D. (2004) Viral interactions with the Notch pathway. Semin. Cancer Biol. 14, 387-396.

174 Ansieau, S., Strobl, L.J. and Leutz, A. (2001) Activation of the Notch-regulated transcription factor CBF1/RBP-Jkappa through the 13SE1A oncoprotein. Genes Dev. 15, 380-385.

\section{To access this journal online: http://www.birkhauser.ch/CMLS}

